\title{
Reassessing the age of Atapuerca-TD6 (Spain): new paleomagnetic results
}

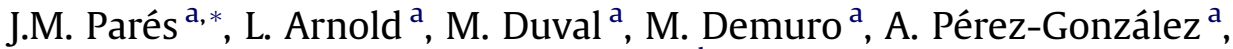 \\ J.M. Bermúdez de Castro ${ }^{a}$, E. Carbonell ${ }^{\text {b }}$, J.L. Arsuaga ${ }^{c}$ \\ ${ }^{a}$ Research Center for Human Evolution (CENIEH), Paseo Sierra de Atapuerca s/n, 09002 Burgos, Spain \\ ${ }^{\mathrm{b}}$ Institut de Paleoecologia Humana i Evolució Social, Àrea de Prehistòria, U. Rovira i Virgili, Plaça Imperial Tarraco 1, E-43005 Tarragona, Spain \\ ${ }^{c}$ Centro de Investigación (UCM-ISCIII) de Evolución y Comportamiento Humanos, Monforte de Lemos 3-5 (Pabellón 14), 28029 Madrid, Spain
}

Keywords:

Atapuerca Gran Dolina TD6

Hominins

Geochronology

Paleomagnetism

\begin{abstract}
A B S T R A C T
We carry out a new paleomagnetic study across stratigraphic layer TD7 of Gran Dolina Site, Atapuerca, and reassess the existing absolute ages (thermoluminescence, electron spin resonance) obtained at this site. The new and more detailed magnetostratigraphic record of the Matuyama-Brunhes boundary, combined with absolute ages, enables further constraint on the age of the underlying human-bearing level or Aurora Stratum. Paleomagnetism of the studied silts and sandstones reveals stable, dual polarity Characteristic Remanent Magnetization directions. A new normal magnetic polarity short interval is found at several consecutive sampling localities in the upper part of TD7, providing a new ante quem date for the human-bearing sediments of 0.9 Ma, possibly formed during MIS 25.
\end{abstract}

\section{Introduction}

A number of key findings at the Lower Palaeolithic cave site of Gran Dolina, Sierra de Atapuerca, northern Spain, have led to major advancements in our knowledge of human evolution and occupation of Eurasia. Since 1995, when the first hominin remains were reported (Carbonell et al., 1995), the site has produced thousands of fossils and artifacts and has become a Pleistocene landmark in studies on early human settlement outside the African continent. The so-called Aurora Stratum of the TD6 level (Carbonell et al., 1995; Parés and Pérez-González, 1995) was excavated between 1994 and 1996 while opening a test pit of about $7 \mathrm{~m}^{2}$ in the Gran Dolina cave site. This excavation yielded a total of 90 human fossil remains (Bermúdez de Castro et al., 1997), 268 lithic artifacts made of flint, sandstone, limestone, and quartz, classified as Mode 1 (Carbonell et al., 1999), as well as several thousand small and large vertebrate animal remains (Cuenca-Bescós et al., 1999; García and Arsuaga, 1999; Made, 1999; Sánchez-Marco, 1999). The most conspicuous hominin findings of the 1994 and 1995 field seasons include a partial face of a juvenile individual, ATD6-69, and a mandibular fragment of a juvenile individual, ATD6-5, together

\footnotetext{
* Corresponding author.

E-mail address: jmpares@umich.edu (J.M. Parés).
}

with a set of isolated teeth of the same individual, that constitutes the holotype of the species Homo antecessor (Bermúdez de Castro et al., 1997). A new excavation of TD6 made between 2003 and 2007 near the test pit of the 1990's allowed us to expand the excavated area to about $13 \mathrm{~m}^{2}$. As a result of this new excavation, the $H$. antecessor human hypodigm now includes near 150 fossil remains, belonging to a minimum of eleven individuals (eight immature and three adults). Key amongst these finds is an almost complete left half mandible, ATD6-96 (Carbonell et al., 2005), from an adult female, and a left half mandibular fragment, ATD6-113 (Bermúdez de Castro et al., 2008), from another adult hominin. The comparative study of these specimens changed previous conclusions about the phylogenetic relationships of $H$. antecessor and suggests that this species represents an oldest and probably European extinct lineage, different from other African lineages, and closer to Asian hominins like those of Zhoukoudian. Also of interest are two humeri, ATD6-121 (immature), and ATD6-148 (adult), which exhibit some of the previously assumed derived Neandertal features at the distal epiphysis (Bermúdez de Castro et al., 2012).

In 1995, a magnetostratigraphic section at Gran Dolina revealed an up section, reverse-to-normal polarity change within the TD7 stratigraphic layer, about $1 \mathrm{~m}$ above the Aurora Stratum (Parés and Pérez-González, 1995, 1999). This major magnetic polarity change was interpreted as the Matuyama-Brunhes (MB therein) boundary, which is known to occur at 780 ka (Shackleton et al., 1990; Lourens 
et al., 2004), although recent isotope age models (Channell et al., 2010 ) indicate a slightly younger age of $773.1 \mathrm{ka}$. The biostratigraphic record for these deposits also supports the paleomagnetic interpretation (e.g., Cuenca-Bescós et al., 1999; García and Arsuaga, 1999), as well as absolute dating including combined Uraniumseries/Electron Spin Resonance (ESR) on fossil teeth (Falguères et al., 1999) and thermoluminescence (TL) (Berger et al., 2008), although details will be discussed later.

Following our initial magnetostratigraphic study (Parés and Pérez-González, 1995, 1999), the aspect of the excavation front at TD6 has changed considerably due to ongoing field work. Specifically, successive field seasons have extended the outcrop towards the north and south, exposing an area of about $13 \mathrm{~m}^{2}$ and providing new outcrops of both stratigraphic levels TD6 and TD7, which did not exist in 1994. These developments have provided an ideal opportunity to revisit stratigraphic unit TD7 immediately adjacent to the human-bearing silts and clays of the Aurora Stratum. In this paper we report new paleomagnetic data with the aims of complementing the initial chronological data and further refining the chronology of stratigraphic layer TD6.

\section{Geological setting}

The Sierra de Atapuerca mountain range, in the northern Iberian Plateau, is a gentle sloping highland, about $10 \mathrm{~km}$ long and less than $2 \mathrm{~km}$ wide, which trends NNW-SSE for the most part and veers towards an $\mathrm{E}-\mathrm{W}$ trend in its northern section. The relief of the range is mostly dictated by upper Cretaceous limestones and dolomites, though there are also outcrops of Albian sands (Utrillas Fm.), Triassic evaporites and Triassic-Jurassic carbonates in the northern segment (Pineda, 1997). The Atapuerca mountain range contains a rich variety of karstic cavities and fissures of a phreaticvadose origin within Cretaceous limestones and dolomites.

Several caves of the Atapuerca karst system contain archaeological and paleontological remains that have been the focus of numerous studies since the 1980's (see Aguirre et al., 1990; Arsuaga et al., 1997; Carbonell et al., 2008 and references therein). Detailed descriptions of the geology and karst development of the archaeological site can be found in Martín et al. (1981), Zazo et al. (1983), Pérez-González et al. (1995) and Ortega et al. (2010) amongst others. An early 1900 s railway cutting revealed numerous fissures and caves on the slopes of the Sierra de Atapuerca. Many of the cave infilling sediments were found to be very rich in paleontological remains (Torres, 1976; Aguirre et al., 1990 and references therein). The railway sites include Gran Dolina, where the new species $H$. antecessor, of Early Pleistocene age, was discovered (Carbonell et al., 1995; Parés and Pérez-González, 1995; Bermúdez de Castro et al., 1997; Cuenca-Bescós et al., 1999; Parés and Pérez-González, 1999; Falguères et al., 1999), Galería (Pérez-González et al., 2001; Carbonell et al., 1999), and Sima del Elefante (Carbonell et al.,
1999; Cuenca-Bescos et al., 2004; Parés et al., 2006). In addition, The Cueva Mayor system contains a number of archaeological sites, including Sima de los Huesos, Portalón, and Galería del Sílex (Fig. 1). Together, the railway sites and the Cueva Mayor constitute what is known as the Sierra de Atapuerca archaeological complex. This archaeological site was added to UNESCO's World Heritage List in 2000 and has become a key Eurasian paleoanthropologic and paleontologic locality.

Atapuerca Gran Dolina shows an 18 m-thick sedimentary sequence divided in 11 stratigraphic units named TD1 to TD11 from bottom to top, and where several hominin occupations have been identified (see review in Rodríguez et al., 2011). Further details of the stratigraphy at Gran Dolina can be found in Parés and PérezGonzález (1999), Canals et al. (2003) and Bermúdez de Castro et al. (2008). Stratigraphic layer TD6 is characterized by several decimetric layers of gravels, silt and clays, with a total thickness of about $200 \mathrm{~cm}$; although there is some lateral variability in sediment thickness. Canals et al. (2003) defined a number of archaeostratigraphic levels within TD6. The Aurora Stratum itself (the lower part of TD6) comprises up to six well differentiated levels, now grouped under 'Aurora Archaeostratigraphic Set' (Bermúdez de Castro et al., 2008). All six layers contain either artifacts or hominin remains. Level TD7 - the main target of our study - is a $\sim 100 \mathrm{~cm}$-thick layer of laminated reddish yellow calcareous sands and cemented gravels. TD7 is capped by a flowstone up to $15 \mathrm{~cm}$ thick, and several meters long.

\section{Existing chronology for TD6-TD8 layers}

Stratigraphic layers TD6 to TD8 have been chronologically constrained by a combination of relative and absolute dating methods, namely paleomagnetism, biostratigraphy, thermoluminescence (TL) and Electron Spin Resonance (ESR).

Recently, Cuenca-Bescós and García (2007) divided the paleontological record of Atapuerca into 7 local faunal zones (Atapuerca Faunal Units, or ATA FUs) based on the distribution of both largeand small-mammal fauna. Three of these ATA FUs were identified within the TD6-TD7 layers. The lower part of TD6 belongs to the ATA FU3, which is characterized by the co-occurrence of the rodents Allophaiomys chalinei and Micromys minutus and the large mammals Homotherium cf. latidens and Sus scrofa (Cuenca-Bescós and García, 2007). The Aurora Stratum of TD6 was integrated into ATA FU4, which is mainly characterized by the occurrence of $H$. antecessor (see further details in Cuenca-Bescós and García, 2007; Cuenca-Bescos et al., 2010, 2011). Finally, ATA FU5 was correlated to TD7 and the bottom part of TD8 and is defined by, among others, the co-occurrence of Microtus ratticepoides, cf. Praeovibos priscus, Iberomys huescarensis, Pliomys episcopalis and Mimomys savini. Based on microfaunal evidence, these 3 faunal units were included within the Allophaiomys chalinei biozone, which is defined by the

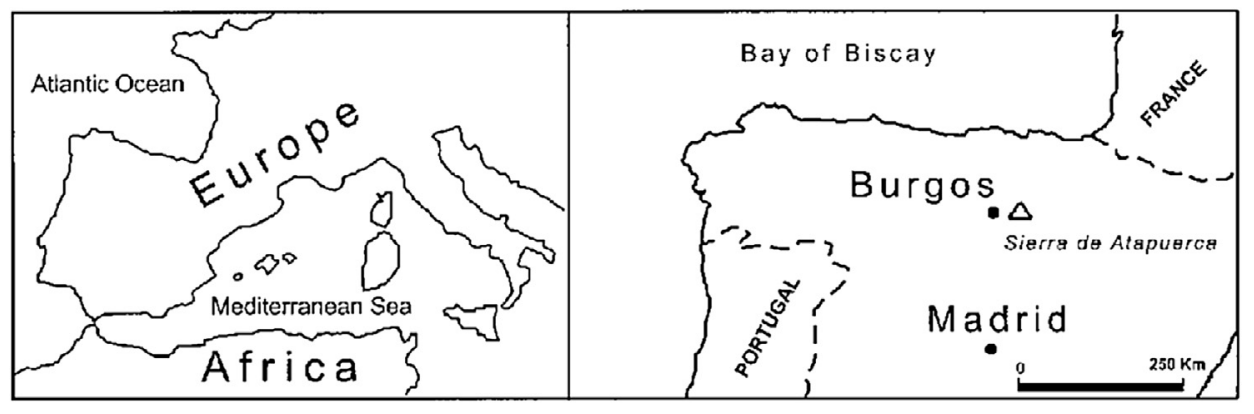

Fig. 1. Location of Atapuerca archaeological site, N Spain. 
association of I. huescarensis, Stenocranius gregaloides, A. chalinei, P. episcopalis and M. savini (Cuenca-Bescós et al., 2010). According to these authors, this biozone chronologically spans the Jaramillo Subchron and the MB boundary, i.e. 0.98-0.78 Ma. The rodent evidence suggest that the TD6-TD7 layers are biochronologically younger than Atapuerca Sima del Elefante TE9 level, as well as Barranco León and Fuente Nueva-3 (Orce, Spain), where Allophaiomys lavocati has been identified (Cuenca-Bescós et al., 2010; Agustí et al., 2007) and which have a pre-Jaramillo chronology (Carbonell et al., 2008; Duval et al., 2012; Oms et al., 2000).

Combined U-series/ESR ages ("US model", Grün et al., 1988) have been obtained by Falguères et al. (1999) on twelve fossil teeth from the upper part of the cave infilling sequence at Gran Dolina. The US-ESR chronology is consistent with the stratigraphy, paleomagnetic data and biochronological interpretations, yielding weighted mean ages ranging from $0.34 \pm 0.03$ Ma for TD11 to $0.73 \pm 0.06$ Ma for TD6. Three fossil teeth were dated from layer TD6, which were collected at the base of the Aurora stratum, $\sim 1.5 \mathrm{~m}$ below the MB boundary identified by Parés and Perez-Gonzalez, (1999). The three ages obtained on these teeth are in agreement, although one age is slightly younger (AT9601: $0.68 \pm 0.10 \mathrm{Ma}$ ) than the other two (AT9602: $0.76 \pm 0.11 \mathrm{Ma}$ and AT9603: $0.77+0.12 \mathrm{Ma})$. A weighted mean age of $0.73 \pm 0.06 \mathrm{Ma}$ was therefore calculated for the TD6 fossil remains and has been subsequently used as a reference for the TD6 layer (Berger et al., 2008; Rodriguez et al., 2011), even though it was taken below the MB boundary. In addition, the TD7 layer was also constrained by three teeth dated from TD8, about $1.5 \mathrm{~m}$ above the MB boundary, which yielded a mean age of $0.60 \pm 0.05 \mathrm{Ma}$ (Falguères et al., 1999).

TL ages of $820 \pm 140 \mathrm{ka}$ and $960 \pm 120 \mathrm{ka}$ have been obtained from the lower TD8 deposits lying $\sim 20 \mathrm{~cm}$ above the existing MB boundary, and from the underlying basal TD7 deposits situated $\sim 20 \mathrm{~cm}$ above the contact with TD6, respectively (Berger et al., 2008). These TL ages were obtained from siliciclastic polymineral fine grain $(4-11 \mu \mathrm{m})$ fractions of unheated sediments, assuming solar resetting of the luminescence signal to a low and measurable residual level prior to burial. Equivalent doses $\left(D_{\mathrm{e}}\right)$ were determined from potassium feldspar-dominated blue-violet $(420 \mathrm{~nm}) \mathrm{TL}$ emissions using the 'total-bleach' multiple-aliquot additive dose (MAAD) method (e.g. Aitken, 1985; Forman, 1989); which involves subtraction of a laboratory determined residual that is presumed to be similar to the unbleached signal remaining in nature. Very long duration, low temperature preheats $\left(\sim 200{ }^{\circ} \mathrm{C}\right.$ for $\left.48 \mathrm{~h}\right)$ were employed for $D_{\mathrm{e}}$ determination and delays of $\geq 2$ months were included between successive irradiations and preheats, as well as before each TL signal measurement. Environmental dose rates were calculated from thick-source alpha counting (uranium and thorium) and atomic absorption spectroscopy (potassium) performed on separate sediment subsamples. The final TL ages for TD8 and TD7 are in stratigraphic order, are in agreement with the presence of the MB boundary in upper TD7, and are consistent with the US-ESR ages and biostratigraphic age-control from TD8. Both the TL ages are systematically older than the weighted mean ESRU-series age for the underlying TD6 deposits, though the two chronological datasets are compatible within their respective $1 \sigma$ error ranges.

\section{Sampling and laboratory methods}

Successive field seasons after 1995 expanded the archaeological excavation towards the north and south, exposing an area of about $13 \mathrm{~m}^{2}$ and providing new outcrops of both stratigraphic levels TD6 and TD7, which did not exist in 1994. We focussed on the fine grained sediments in the upper part of TD7, as the grain size is much coaser towards the bottom preventing any meaningful paleomagnetic study. For our new paleomagnetic study, samples were obtained in the field using two different methods, owing to differences in rock/sediment cohesiveness. For flowstone sampling, we used a standard gasoline powered portable drilling machine, equipped with a 1-inch non-magnetic drill bit. Soft, non-cohesive clay and silty deposits were sampled by hammering a brass tube with a reinforced stainless steel tip into the cleaned outcrop surface at a specified angle. Where necessary, sediment samples were then impregnated with a water solution of sodium silicate (1:1) for solidification prior to extraction. Orientation of the cores was achieved using a standard orientation device (compass-inclinometer) to obtain the in situ azimuth and dip of the samples. All samples were sliced in the laboratory to obtain standard $2.54 \mathrm{~cm} \times 2.11 \mathrm{~cm}$ length specimens.

Natural Remanent Magnetization (NRM) and its progressive demagnetization were measured with a three-axis 2G SQUID magnetometer housed in a field-free room. The noise level of the magnetometer is $\sim 7 \mu \mathrm{A} / \mathrm{m}$, well below the magnetization intensity of the measured samples. Specimens were demagnetized either thermally in an ASC Thermal Demagnetizer, or using the in-line Alternating Field capability of the rock magnetometer. Characteristic Remanent Magnetization component directions were calculated for all specimens using Principal Component Analysis (Kirschvink, 1980), guided by visual inspection of orthogonal demagnetization plots (Zijderveld, 1967).

\section{Results}

Samples were generally well-behaved upon thermal or alternating field demagnetization (Fig. 2), and therefore we mostly used the latter for cleaning purposes. Sister samples (e.g. GD7-14A and GD7-14B, Fig. 2) reveal that both methods, thermal and alternating field, are equally efficient in removing viscous magnetization in the studied lithology. Detailed rock-magnetic analyses of the studied sediments have been previously reported elsewhere (Parés and Pérez-González, 1995, 1999). Natural Remanent Magnetization (NRM) intensities were on the order of $0.5-9 \mathrm{~mA} / \mathrm{m}$, well above the noise level of the cryogenic magnetometer, and resulted in demagnetization paths that were very clean and stable (Fig. 2). Typically a soft component was removed by $10-16 \mathrm{~T}$ or $200{ }^{\circ} \mathrm{C}$, above which demagnetization level the intensity decays linearly towards the origin. The Characteristic Remanent Magnetization (ChRM) directions are southward and negative (Fig. 2) or northward and positive (Fig. 2), showing distinctively reverse and normal magnetization directions respectively (Table 1). Maximum unblocking temperatures $\left(600^{\circ} \mathrm{C}\right)$, and median destructive field values suggested the presence of magnetite as the main ferromagnetic mineral responsible for the remanence. This observation is consistent with previous results obtained in similar sedimentary rocks and flowstones from Atapuerca archaeological site (e.g., Parés and Pérez-González, 1995, 1999; Pares et al., 2006), and for cave deposits (e.g., Bosák and Pruner, 2011) and speleothems analyzed elsewhere (Perkins and Maher, 1993; Latham and Ford, 1993).

The magnetostratigraphy of the re-sampled interval is shown in Fig. 3 (right-hand plot), expressed as Virtual Geomagnetic Pole Latitude (VGP Lat), and compared with the previous results of Parés and Pérez-González (1995, 1999) (left-hand plot in Fig. 3). Slight mismatch of layers thickness are evidentdue to lateral changes in the thickness of the strata (e.g., Canals et al., 2003; Bermúdez de Castro et al., 2008). Our new study focused on a vertical depth of ca $200 \mathrm{~cm}$ across the previously reported MB boundary and, overall, our results confirm the existing paleomagnetic interpretations. Nevertheless, the narrower sampling spacing afforded by the present study (ca up to $15 \mathrm{~cm}$ ) enables a higher resolution analysis of the general $\mathrm{R} \rightarrow \mathrm{N}$ trend. Stratigraphic layer TD6, which includes 
Gran Dolina (TD7) Demagnetization Data
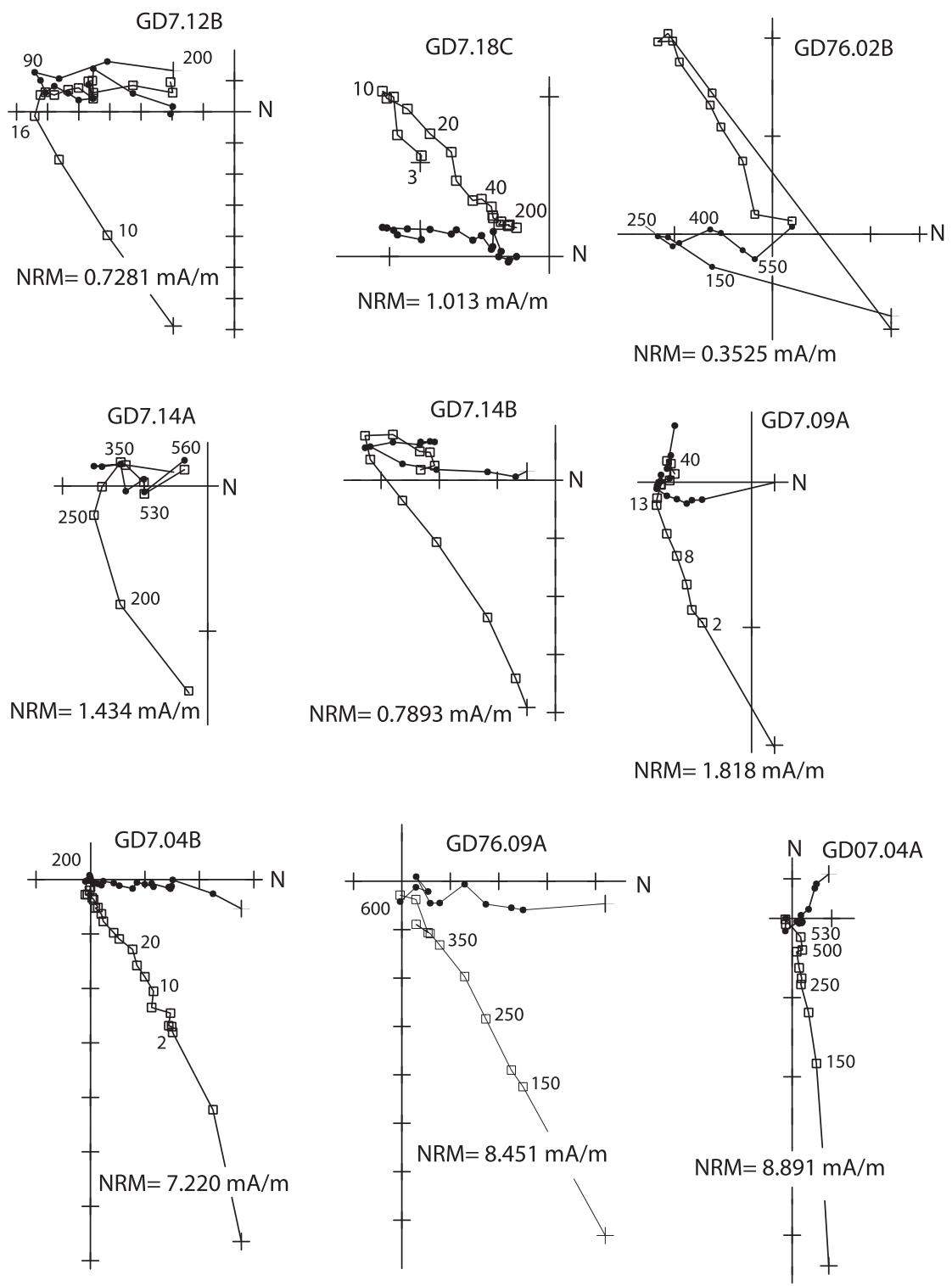

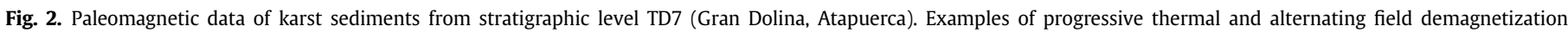

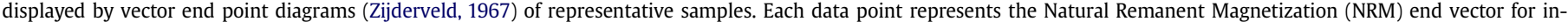

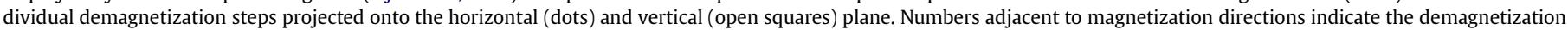

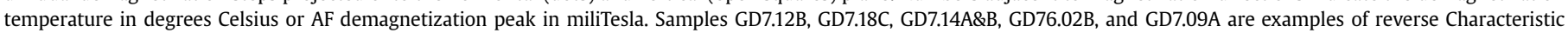
Remanent Magnetization (ChRM) directions, whereas samples GD7.04B, GD76.09A, and GD7.04A of normal ChRM. Initial value of NRM (in mA/m) is also shown.

the Aurora Stratum, falls within the Matuyama Chron, as already described by Parés and Pérez-González (1995, 1999). However, in that study the $\mathrm{R} \rightarrow \mathrm{N}$ boundary was observed in the middle part of unit TD7, whereas our new study, based on higher density sampling, reveals a younger reversed magnetochron in the upper part of unit TD7 (R2 in Fig. 3). Clastic sediments overlying the flowstone display normal polarity magnetization (N2) and remain positive from TD8 to TD10 (Parés and Perez-González, 1999). Although other options are possible (see following discussion), the R2-N2 boundary within upper TD7 most likely represents the MatuyamaBrunhes reversal. As discussed earlier, such interpretation matches both biostratigraphy data and existing TL and US-ESR ages (Fig. 4).

Our new paleomagnetic results furnish new data relevant to the age of both TD7 and TD6. Specifically, we find a dominantly normal interval (N1) in the upper part of TD7. Single horizons (=sampling interval) surrounded (above and below) by different polarity sites are considered as undetermined. The appearance of such short, normal polarity interval (N1) in TD7 level allows further refinement of the existing chronology of this part of the stratigraphic section. In order to interpret the significance of the magnetostratigraphy we need to scrutinize the limits of the absolute ages obtained with both TL and US-ESR.

\section{Discussion}

\subsection{Reassessing the absolute ages}

The ages of $820 \pm 140 \mathrm{ka}$ and $960 \pm 120 \mathrm{ka}$ obtained by Berger et al. (2008) from lower TD8 and TD7 are perhaps the oldest feldspar TL chronologies published so far and merit closer consideration as: (i) they exceed the conventional dating limits of standard feldspar TL techniques in environments with 'average' dose rates 
Table 1

Paleomagnetic results by sampling site. Site classification: Class 1 if precision parameter $k$ is greater than 10 , class 2 if is less than 10 and class 3 if one specimen is used. Long, Lat - Longitude and Latitude of the Virtual Geomagnetic Pole; n number of specimens.

\begin{tabular}{lcclll}
\hline Site & Long & Lat & $\mathrm{n}$ & Class & Height $(\mathrm{cm})$ \\
\hline TDN80-1,2 & 256 & 63 & 2 & 2 & 235 \\
TDN70-8,9 & 96 & 73 & 2 & 1 & 215 \\
GD7-18 & 323 & -68.8 & 3 & 1 & 207 \\
GD7-17 & 38.8 & -68.2 & 1 & 3 & 207 \\
GD7-16 & 87 & -75.8 & 1 & 3 & 207 \\
GD76-02 & 277.4 & -84.7 & 2 & 1 & 206 \\
GD7-11 & 330.6 & -49.8 & 2 & 1 & 177 \\
GD7-12 & 335.7 & -50.7 & 2 & 1 & 177 \\
GD7-14 & 345.3 & -51.2 & 2 & 1 & 177 \\
GD76-06 & 97.3 & 75.4 & 2 & 2 & 175 \\
GD7-01 & 57 & 57.8 & 2 & 1 & 175 \\
GD7-02 & 337 & 57.6 & 2 & 2 & 175 \\
GD76-07 & 103.7 & 75.4 & 2 & 1 & 175 \\
TDN70-7 & 349 & -58 & 2 & 2 & 172 \\
GD7-04 & 25.8 & 74.1 & 1 & 3 & 168 \\
GD76-09 & 108 & 78.4 & 2 & 1 & 164 \\
GD76-12 & 87.9 & 77.8 & 1 & 3 & 161 \\
GD7-06 & 53 & 54 & 2 & 1 & 161 \\
TDN70-4,5 & 80 & -60 & 2 & 2 & 160 \\
GD7-08 & 266.7 & -65.2 & 1 & 3 & 150 \\
TDN70-1,2 & 43 & -74 & 2 & 1 & 148 \\
TDN17-1,2 & 350 & -55 & 2 & 1 & 146 \\
GD7-09 & 317.4 & -42.6 & 2 & 1 & 140 \\
GD76-14 & 92.8 & 64 & 1 & 3 & 138 \\
TDN15 & 31 & -71 & 2 & 2 & 80 \\
TDN14 & 310 & -58 & 1 & 3 & 18 \\
\hline
\end{tabular}

(e.g. Berger, 1994; Roberts, 1997; Stokes, 1999); (ii) they are based on a method of $D_{\mathrm{e}}$ determination that is not best-suited for old deposits and complex sedimentary contexts such as karstic cave infills (i.e., MAAD total-bleach); (iii) TL signals are optically reset at considerably slower rates than optically stimulated luminescence (OSL) signals (i.e. hours or days instead of seconds or minutes; e.g.,
Godfrey-Smith et al., 1988) and it is unlikely that the rapidly accumulated slopewash deposits at Gran Dolina received sufficient direct sunlight exposure before burial to prevent incomplete resetting ('partial bleaching') of the pre-existing TL signal; and (iv) the $D_{\mathrm{e}}$ estimates are derived primarily from potassium feldspars, which are apt to suffer from age underestimation related to longterm instability of the TL signal accumulated during burial ('anomalous fading') (e.g. Wintle, 1973; Aitken, 1985; Huntley and Lamothe, 2001).

Fig. 6 of Berger et al. (2008) shows that the natural TL signal of the TD7 sample is approaching 50\% of the dose saturation level, necessitating significant extrapolation of the MAAD dose-response curve for $D_{\mathrm{e}}$ calculation and introducing potential uncertainties over the appropriateness of the selected sublinear curve-fitting model (e.g. Duval et al., 2009). The $D_{\mathrm{e}}$ values obtained for this sample across the integrated TL glow curve region $\left(280-370{ }^{\circ} \mathrm{C}\right)$ also do not form a flat preheat plateau but instead increase steadily with temperature (i.e., by up to $50 \%$ or $100 \%$, depending on preheat conditions). Such trends can indicate inadequate removal of thermally unstable TL peaks (owing to the selection of insufficiently stringent preheats) or insufficient resetting of hard-to-bleach TL peaks prior to deposition (Aitken, 1998; Berger, 2011). It is difficult to assess the implications of these potential sources of $D_{\mathrm{e}}$ uncertainty, though it is possible that any resultant age inaccuracies may have been masked by the already large (10-30\%) $1 \sigma$ error margins.

The feldspar TL ages for TD7 and TD8 were not corrected for anomalous fading because it was argued that the use of prolonged preheats and delayed TL measurements had adequately isolated a non-fading or 'post-fading' additive dose signal (see also Berger, 2011). This could be true, though the absence of fading under these experimental conditions has not been explicitly demonstrated for these samples. Anomalous fading has been discounted on the basis of agreement with independent age control for TD7 (e.g. the existing B-M boundary). However, this seemingly favorable outcome may simply reflect the fortuitous interplay of opposing

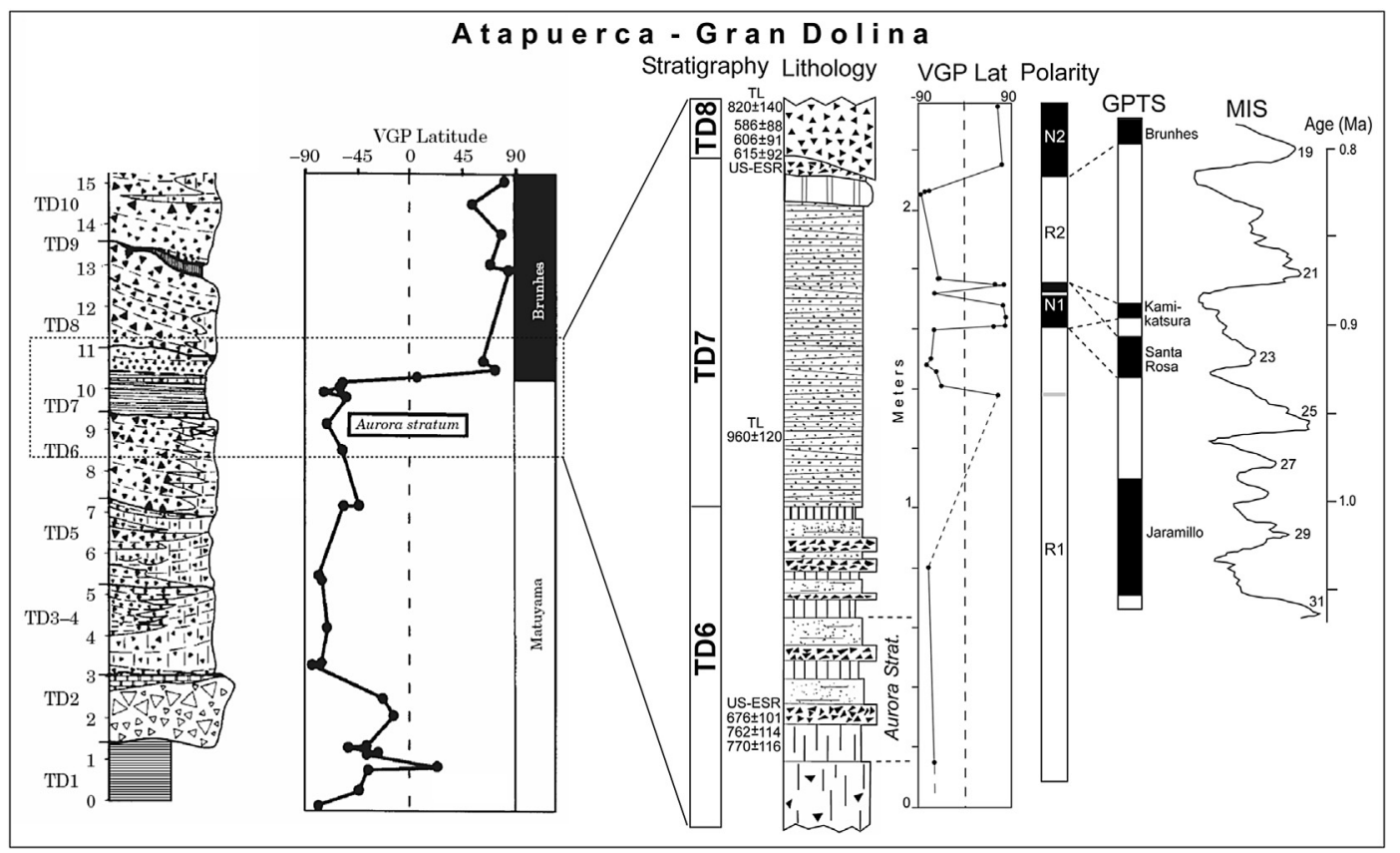

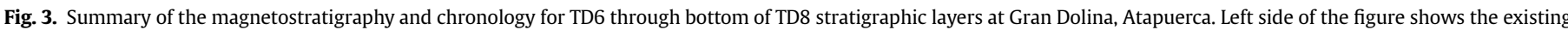

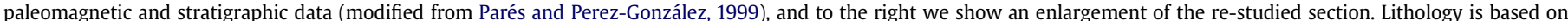

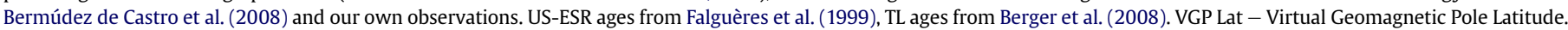
GPTS - Geomagnetic Polarity Time Scale. MIS - Marine Isotope Stage (redrawn from Lisiecki and Raymo, 2005). 


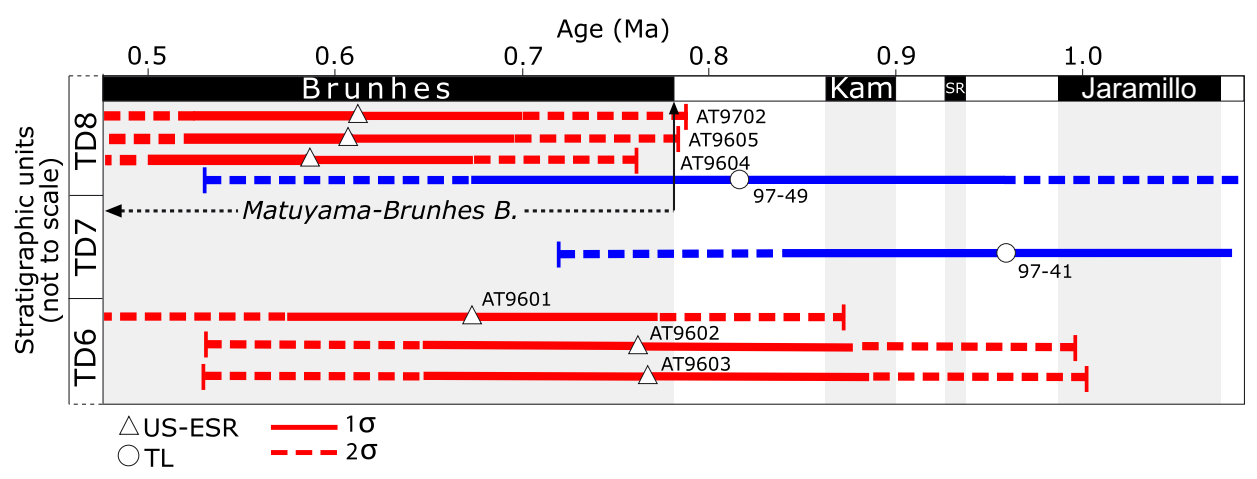

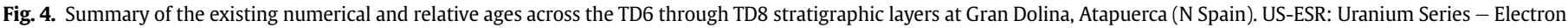

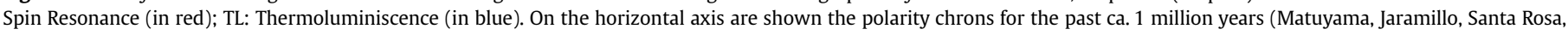

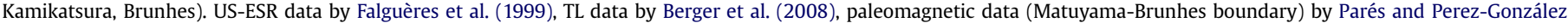
(1999). (For interpretation of the references to color in this figure legend, the reader is referred to the web version of this article.)

systematic inaccuracies in this instance (i.e., anomalous fading versus partial bleaching). Moreover, anomalous fading of up to $\sim 40 \%$ was observed over a 4.5 year storage period for two associated samples from TD10 and TD11. If anomalous fading had similarly affected the TD7 and TD8 samples, the uncorrected TL ages should perhaps be regarded as minima (Fig. 4).

The limited potential for daylight exposure during alluvial infilling events at Gran Dolina, and the potential for incorporation of unbleached grains from roof-collapsed material and interiorfacies, means it is important to demonstrate that the TL signals of the TD7 and TD8 samples were well bleached at deposition. Berger et al. (2008) show that the rapidly bleached infrared stimulated luminescence (IRSL) signals of nearby surface soil samples yielded remnant ages of $<7 \mathrm{ka}$, however the same basic tests were not performed on the more slowly bleached TL signals of modern analogues. Replicate IRSL and TL ages were presented for 9 samples and the latter were on average $>90 \%$ older than the former. This replicate age offset partly reflects differing dose-saturation properties of the IRSL and TL signals, but it may also be a sign of significantly larger TL residual doses for some of the samples. If the TD7 and TD8 sediments had been insufficiently bleached prior to deposition, it would necessitate use the 'partial bleach' rather than 'total bleach' MAAD method for $D_{\mathrm{e}}$ determination because of major uncertainties in determining a representative laboratory bleached residual.

In sum, TL signal resetting remains largely unconstrained for the TD7 and TD8 samples, but it seems possible that partial bleaching has had at least some influence on the final chronologies. Such systematic age overestimations could account for the older ages obtained for TD7 and TD8 in comparison with the underlying USESR series ages for TD6. As such, we cautiously interpret the existing TL chronologies for TD8 and TD7 as maximum age estimates. If anomalous fading were an additional problem with these samples, it could have acted to moderate the likely age overestimations resulting from partial bleaching; indeed, this might explain the broad agreement (at $1 \sigma$ ) with independently established chronologies for levels TD8 and TD7.

As far as US-ESR ages are concerned, a recent study has showed that the chronology of AT9601 was probably underestimated in comparison with the other two ages obtained for TD6 (Duval et al., 2012). The apparent U-series ages obtained for cement and dentine from this tooth sample ( $>350 \mathrm{ka}$ ) are close to the limit of the US model (Grün et al., 1988), leading to a likely overestimation in the dose rate for these tissues. In contrast, the corresponding ages obtained for AT9602 and AT9603 appear to be more reliable. The weighted mean combined US-ESR age of $0.77 \pm 0.08$ Ma $(1 \sigma)$ extracted from these two samples, therefore, provides a more reliable age estimate for TD6 (Fig. 4). A similar reanalysis of the existing US-ESR data may be warranted for the samples from TD8, located above TD7. The sampled teeth from this level came from the middle of TD8 and were found stratigraphically below a hiatus characterized by the last occurrence of $M$. savini (Falguères et al., 1999) at the top of TD8 (Cuenca-Bescós et al., 2010). The US-ESR age of AT9604 from TD8 was obtained by fixing the p-parameter to -1 in the enamel, since the ${ }^{230} \mathrm{Th} /{ }^{234} \mathrm{U}$ activity ratio measured in that tissue was above secular equilibrium. This procedure leads to a systematic overestimation of the dose rate (Duval, 2008), suggesting that the resultant age may be an underestimate. Consequently, the ages obtained for the two remaining samples from TD8 are considered more reliable, and a weighted mean age of $0.61 \pm 0.07$ Ma may be obtained for this unit. The former paleomagnetic study by Parés and Perez-González (1999) reveals that the Matuyama-Brunhes boundary $(780 \mathrm{ka})$ is found at about $100 \mathrm{~cm}$ below the bottom of TD8. On the other hand, TD6 has a weighted mean age of $0.77 \pm 0.08 \mathrm{Ma}(1 \sigma)$. Therefore, the combined paleomagnetic results with the US-ESR $2 \sigma$ age range, indicates that TD6 level was most likely deposited between 0.78 and $0.93 \mathrm{Ma}$ (Fig. 4).

\subsection{Interpreting the paleomagnetic data}

In the light of the TL and US-ESR ages, three different hypotheses can be put forward to explain the observed sequence of VGP latitudes:

(i) The magnetization directions of short normal interval N1 are secondary rather than primary, i.e., a somewhat confined remagnetization.

(ii) The reversed interval in the upper part of TD7 (R2) is a short polarity event within Brunhes, and therefore the MatuyamaBrunhes reversal is the $\mathrm{R} 1 \rightarrow \mathrm{N} 1$ transition.

(iii) Magnetozone N1 represents a short polarity interval preceding the Matuyama-Brunhes boundary, either the Jaramillo Subchron or the Kamikatsura-Santa Rosa short chrons all together.

Although standard paleomagnetic stability tests cannot be performed in such sedimentary depositional environment (i.e., fold test, conglomerate test), there is no reason to suspect that magnetization directions that define magnetozone N1 are not of primary origin (hypothesis (i)). We do not observe any differences in demagnetization behavior, stability, or intensity, nor are the 
boundaries of the magnetozone coincident with any marked lithological, grain size or color changes.

As far as suggestion (ii), there are a number of excursions and short polarity intervals during the Brunhes Chron, although most of them are still under debate (e.g., Laj and Channell, 2007). The geomagnetic field behavior and precise chronology of the purportedly intra-Brunhes events are often not well defined. For example, in a recent paper, Cox et al. (2012) obtained ages for the well known Mono Lake excursion $(38.7 \pm 1.2 \mathrm{ka})$ at its type locality that are indistinguishable from the Laschamp excursion ( $40 \pm 2 \mathrm{ka}$ ). The oldest excursion or event within Brunhes is the so-called "Stage 17" (e.g. Laj and Channell, 2007), or "Event $17 \alpha$ " of Channell and Raymo (2003), which probably corresponds to the "Delta" paleointensity low, first labeled as such in the ODP leg 138 paleointensity record (Valet and Meynadier, 1993) and also noticed by Channell et al. (2004) at sites 984 and 983, in the North Atlantic. The estimated age for this event is $\sim 690 \mathrm{ka}$, or equivalent to marine isotopic stage (MIS) 17 (hence the name of the event). To date, all records of this event (Valet and Meynadier, 1993; Biswas et al., 1999; Lund et al., 2001; Channell et al., 2004) have documented excursional paleomagnetic directions and a low in the relative paleointensity record, rather than a genuine reversal (e.g., antipodal directions) such as that observed in TD7. Even though this hypothesis is compatible with the US-ESR chronology, biochronological evidence, as discussed earlier (e.g., Cuenca-Bescós and García, 2007; Cuenca-Bescós et al., 2011), would not support a stage 17 interpretation for upper TD7.

As far as (iii) the subchron C1r.1n of the Geomagnetic Polarity Time Scale (GPTS), better known as Jaramillo, was first reported in a paper that became a historical marker in 1966 (Doell and Dalrymple, 1966) and it takes its name after the Jaramillo Creek, in the Jemez Mountains of New Mexico, where an extensive volcanic complex is found. The age of the Subchron has been determined using ${ }^{40} \mathrm{Ar} /{ }^{39} \mathrm{Ar}$, astronomical tuning, and $\delta^{18} \mathrm{O}$ stratigraphy, and is considered to be 986-987 ka (top Jaramillo) to 1053-1068 ka (bottom). When combined with benthic and planktic $\delta^{18} \mathrm{O}$ records, the Jaramillo Subchron appears to occur during MIS 27-31 (e.g., Channell et al., 2002). As previously detailed, ESR dating provides a maximum age of $0.93 \mathrm{Ma}(2 \sigma)$ for the fossil remains from TD6 (Fig. 2). This age is in disagreement with the assignment of N1 to Jaramillo Subchron, since the dated fossil teeth are located about $1.5 \mathrm{~m}$ below the reversal and should therefore yield a chronology older than 1.07 Ma. In addition this hypothesis would attribute a similar chronology to both TD6 and TE9 layers, whereas the biochronology indicates major differences in age between these two deposits (Cuenca-Bescós et al., 2010). As far as the TL results are concerned, the age of $960 \pm 120 \mathrm{ka}$ obtained $\sim 40 \mathrm{~cm}$ below magnetozone $\mathrm{N} 1$ is considered as a terminus post quem age estimate, as seems appropriate from the aforementioned discussions of partial bleaching. Therefore the existing luminescence chronology of TD7 is not compatible with the hypothesis that the normal polarity interval N1 represents the Jaramillo Subchron. In addition, the interpretation of N1 as Jaramillo would place stratigraphic level TD6 within MIS stages 31 or 33, significantly older than what the faunal record predicts.

The so-called Kamikatsura excursion was first described by Maenaka (1983) who observed excursional magnetization directions in the homonymous tuff in Japan. Further evidence for the Kamikatsura comes from a lava flow at Clear Lake, California dated to $0.83 \mathrm{Ma}$, where it is recorded by genuine normal polarity directions (Mankinen et al., 1981). Singer et al. (1999) documented low virtual geomagnetic polar latitudes in volcanic rocks with ${ }^{40} \mathrm{Ar} /{ }^{39} \mathrm{Ar}$ ages of $880-886 \mathrm{ka}$ and later on of $899 \pm 6 \mathrm{ka}$ (Singer and Brown, 2002) for a truly normally magnetized lava flow in New Mexico. The appearance of the Kamikatsura has been reported in other volcanic rocks, which give confidence of such short polarity event. In lava flows at Maui the
Kamikatsura has an ${ }^{40} \mathrm{Ar} /{ }^{39} \mathrm{Ar}$ age of $900.3 \pm 4.7 \mathrm{ka}$ (Coe et al., 2004), and in Iceland (Tjörnes Peninsula) Camps et al. (2011) interpret transitional directions with an age of $862 \pm 51 \mathrm{ka}$ as the Kamikatsura. Additionally, Chinese loess studies have yielded two excursions in loess L9, which corresponds to MIS 22 (Heslop et al., 2000; Yang et al., 2004), around 0.8 Ma. Interestingly enough, two Paleolithic sites in China give also a hint of the Kamikatsura/Santa Rosa events. In a lacustrine section at Xiantai (N China) a short normal polarity interval between Brunhes and Jaramillo has been observed and interpreted as either Kamikatsura or Santa Rosa (Deng et al., 2006). In the same area, at the Paleolithic site of Donggutuo, Liu et al. (2010) suggest that two short normal polarity intervals correlate with the Kamikatsura and Santa Rosa events.

Marine sediments also seem to have recorded the Kamikatsura event. At ODP Site 983, Channell and Kleiven (2000) report a short interval in MIS 21 with excursional magnetization directions. In piston core LC07, in the Sicily Strait, Dinares-Turell et al. (2002) observe a drop in the relative paleointensity record which is interpreted as eitherSanta Rosa or Kamikatsura. Overall, all these reported ages (volcanic rocks, sedimentary sequences) are very similar to those from the Kamikatsura flow, giving confidence on the Kamikatsura excursion.

The Santa Rosa excursion was originally reported by Doell and Dalrymple (1966) in volcanic rocks from New Mexico, although it was interpreted as the polarity transition at the end of the Jaramillo subchron. Subsequent ${ }^{40} \mathrm{Ar} /{ }^{39} \mathrm{Ar}$ ages by Spell and McDougall (1992) and Izett and Obradovich (1994) on the same rocks give a mean of 922 ka (Singer et al., 1999). Possibly the most convincing evidence for the Santa Rosa is provided by Singer and Brown (2002), who obtained an age of $936 \pm 8 \mathrm{ka}$ and truly normal magnetization directions at Cerro Santa Rosa, in New Mexico. 52 paleomagnetic samples from seven sites reveal stable, normal polarity directions supporting the original paleomagnetic results of Doell and Dalrymple (1966). As mentioned earlier, Liu et al. (2010) interpret a pair of short normal polarity intervals as the Kamikatsura and Santa Rosa respectively in a section at Donggutuo. Marine oceanic sediments provide high-resolution records of the relative paleointensity of the geomagnetic field in the past. Specifically, records from Ontong-Java Plateau (Kok and Tauxe, 1999), equatorial Pacific (Valet and Meynadier, 1993), and California margin (Guyodo et al., 1999) all record a pair of prominent lows in relative paleointensity between the Jaramillo Subchron and the MB boundary, coinciding with the expected position of Kamikatsura and Santa Rosa short polarity intervals at $\sim 0.88 \mathrm{Ma}$ and $0.92 \mathrm{Ma}$ respectively (e.g., Singer et al., 1999).

All together, current data shows the presence of both short normal polarity intervals Santa Rosa and Kamikatsura, postdating Jaramillo and preceeding the MB boundary. Despite all this abundant evidence, some authors (e.g., Valet et al., 2008) consider that both events Kamikatsura and Santa Rosa could be combined as overall they correspond to a large paleointensity drop in the Sint2000 record (Valet et al., 2005). As will be discussed later, whether there is one or two short polarity intervals in that time range is not the goal of this study and does not really change our final interpretation.

Consideration of the existing TL ages for TD8 ( $~ 820 \mathrm{ka})$ and TD7 ( $\sim 960 \mathrm{ka}$ ) as either maximum or finite age estimates would support the hypothesis that the intervening magnetozone $\mathrm{N} 1$ represents the 890-940 ka Kamikatsura-Santa Rosa events rather than Jaramillo. However, improved luminescence dating is needed to better constrain a number of fundamental assumptions and uncertainties with the TL chronologies. In comparison with the other options, the latter hypothesis is also more consistent with the mean US-ESR age obtained on fossil teeth from TD6 $(0.77 \pm 0.16,2 \sigma)$. Indeed, a maximum US-ESR age of $0.93 \mathrm{Ma}$ for TD6 is broadly compatible with 
the Kamikatsura/Santa Rosa events. However, in spite of this consistency, the US-ESR ages still slightly and systematically underestimate the age of Kamikatsura excursion. Based on the data published by Falguères et al. (1999), two potential sources of age underestimation are worth further consideration. The first is linked to the assessment of the external dose rate from the sediment, which represents $\sim 70 \%$ of the total dose rate for each ample (Falguères et al., 1999). This component was assessed by high resolution gamma spectrometry performed in the laboratory, on sediment collected from the closest excavated square, since the original sampling locality no longer existed (see Table 2 from Falguères et al., 1999). However, TD6 layer is documented as a heterogeneous stratigraphic unit consisting of a succession of siltstones with angular clasts forming several distinct sub-layers (e.g., Canals et al., 2003; Bermúdez de Castro et al., 2008). Lateral variations in the composition of TD6, and especially of the Aurora Stratum, have also been observed (Canals et al., 2003). Such vertical and lateral heterogeneities may have an impact on the external dose rate reconstruction, especially because laboratory measurements were performed on a few hundred grams of sediments that were not collected from the immediate surroundings of the sampled teeth. Further repeated in situ measurements should be performed in the Aurora Stratum, in order to assess the magnitude of lateral variations in sediment radioactivity. In addition, recent studies focused on ESR measurements of enamel fragments have identified two main groups of $\mathrm{CO}_{2}^{-}$radicals as major contributors to the overall radiationinduced ESR signal of enamel (see Joannes-Boyau and Grün, 2011 and references therein). These radicals are usually classified as oriented $\mathrm{CO}_{2}^{-}$and non-oriented $\mathrm{CO}_{2}^{-}$radicals, depending on their orientation dependence within the enamel layer and show distinct thermal stabilities and radiation sensitivities. According to JoannesBoyau and Grün (2011), the preferential creation of unstable nonoriented $\mathrm{CO}_{2}^{-}$radicals after laboratory gamma irradiation might potentially induce systematic underestimations in $D_{\mathrm{e}}$ values. However, the magnitude of this potential underestimation is still unclear, since the study was performed on a very limited number of enamel samples and the influence of several factors remain to be accurately assessed (e.g., age of the site, tooth type, species, etc.). Further specific studies would need to be performed on the Gran Dolina fossil teeth before drawing any definitive conclusions about this source of systematic uncertainty. Ongoing studies on optically bleached quartz grains by ESR (Moreno, 2011; Moreno et al., 2011) will also shed light on this issue.

Further support for the Kamikatsura-Santa Rosa interpretation of N1 comes from faunal-based proxy evidence for paleoenvironmental conditions associated with TD7 and TD6. For example, the presence of Castor fiber in the Aurora Stratum is a strong indicator for permanent water courses and open environment in the area (Blain et al., 2008). Birds at TD6 are supportive of a wide open, bushland type landscape, with large bodies of water (SánchezMarco, 1999). TD7, on the other hand, is very poor in small vertebrate remains, but the reptile and amphibian record indicates a high diversity of habitats (Rodríguez et al., 2011). The smallmammal assemblage in Gran Dolina also supports an age of around 1 My for the stratigraphic units TD4-TD6, consistent with the appearance of Kamikatsura/Santa Rosa in TD7. Specifically, units TD4 to TD6 in Gran Dolina are characterized by the faunas of the Allophaiomys chalinei biozone, which postdates the Allophaiomys lavocati in the Iberian Peninsula (Cuenca-Bescós et al., 2013). Together, the large and small faunal records suggest that TD6 formed under a warm, wet, and wooded interval (e.g. García-Antón, 1995; García and Arsuaga, 1999; Cuenca-Bescós et al., 2010). If N1 corresponds to Kamikatsura/Santa Rosa subchrons then TD6 stratigraphic layer would possibly have been formed under MIS 25, more in accordance with the fossil evidence.
A question that follows is the apparent absence of the Jaramillo Suchron in the Gran Dolina section, which might reflect the lack of sedimentation, erosion, or else that is coetaneous with some of the breccias and debris not suitable for paleomagnetism. We note though that in stratigraphic unit TD1, at the very bottom of the sequence, some samples have yielded positive latitudinal virtual paleomagnetic poles, tentatively interpreted as Jaramillo by Parés and Perez-González (1999). Such interpretation is consistent with recent ESR ages on quartz by Moreno (2011), but needs confirmation. Unit TD1 is an autochthonous deposit, made up by laminatated red siltstones, and have not yet been been sampled thoroughly for paleomagnetism. We hope that further sampling of this lower unit will furnish new data that will let us determine whether the Jaramillo chron is recorded in the lower part of Gran Dolina.

\section{Conclusions}

A new paleomagnetic study across stratigraphic layer TD7, at Gran Dolina, Atapuerca, reveals a more detailed magnetostratigraphic record of the Matuyama-Brunhes boundary above the human-bearing Aurora Stratum. A new normal magnetic polarity short interval, given by four consecutive sampling sites, has been found in the upper part of TD7.

The TL ages obtained by Berger et al. (2008) for TD7 and TD8 are cautiously interpreted as maximum age estimates owing to the likelihood of partial bleaching prior to burial. When considered in this manner, the TL chronologies of $<820 \mathrm{ka}$ and $<960 \mathrm{ka}$ for deposits overlying and underlying the new magnetozone are compatible with the interpretation that chron N1 represents the Kamikatsura-Santa Rosa events rather than Jaramillo Subchron. However, additional luminescence studies using extended-range optical dating techniques (raised temperature post-IR IRSL, thermally-transferred OSL, individual quartz 'supergrains'; e.g., Arnold et al., 2013) would be advisable to improve the precision of the existing TL chronologies, and to better constrain uncertainties related to partial bleaching and anomalous fading.

If the new magnetozone N1 is attributed to Kamikatsura/Santa Rosa subchrons then the MB boundary is found stratigraphically slightly higher than previously reported, and it raises some questions about the US-ESR age results. A few potential sources of age underestimation may be envisaged in this regard, namely sediment heterogeneity and/or $D_{\mathrm{e}}$ underestimation. These uncertainties could be addressed by: (i) carrying out repeated in situ gamma spectrometry measurements in order to check for lateral variations in dosimetry, (ii) assessing the amount of unstable radicals in the natural signal of teeth samples, in order to perform ESR intensities corrections for the assessment of the $\mathrm{D}_{\mathrm{e}}$.

Taken together, the current evidence points towards the new magnetozone as the Kamikatsura/Santa Rosa subchrons, which have been dated as 0.899 and 0.936 Ma respectively (Singer and Brown, 2002). The Aurora Stratum including the human fossils is located about $100 \mathrm{~cm}$ below the newly reported subchron, and hence the paleomagnetic record in combination with the re-evaluated TL and US-ESR ages, provides a new ante quem date for the human-bearing silts of $0.936 \mathrm{Ma}$, and possibly formed during MIS 25.

\section{Acknowledgments}

Access and permission to collect samples in Atapuerca was granted by Junta de Castilla y León. Financial support for this work was obtained from Junta de Castilla y León and from MICINN Grants CGL2010-16821 (JMP), CGL2009-12703-C03-01 (JMB), and Fundación Atapuerca. We thank C. Mac Niocaill and an anonymous reviewer for providing incisive comments. 


\section{References}

Aguirre, E., Arsuaga, J.L., Bermúdez de Castro, J.M., Carbonell, E., Díez, M., Enamorado, J., Fernández-Jalvo, Y., Gil, E., Gracia, A., Martín-Nájera, A. Martínez, I., Morales, J., Ortega, A.I., Rosas, A., Sánchez, A., Sánchez, B., Sesé, C., Soto, E., Torres, T.J., 1990. The Atapuerca sites and the Ibeas hominids. J. Hum. Evol. 5, 55-73.

Aitken, M.J., 1985. Thermoluminescence Dating. Academic Press, London, p. 359.

Aitken, M.J., 1998. An Introduction to Optical Dating. Oxford University Press, Oxford, p. 267.

Agustí, J., Oms, O., Pares, J.M., 2007. Biostratigraphy, paleomagnetism and geology of the Orce ravine (Southern Spain). Comment on the paper by Gibert et al. (2006). Quaternary Science Reviews 26, 568-572 http://dx.doi.org/10.1016/j.quascirev. 2006.11.001.

Arnold, L.J., Demuro, M., Navazo Ruiz, M., Benito-Calvo, A., Pérez-González, A., 2013. OSL dating of the Middle Palaeolithic Hotel California site, Sierra de Atapuerca, north-central Spain. Boreas 42, 285-305.

Arsuaga, J.L., Bermúdez de Castro, J.M., Carbonell, E. (Eds.), 1997. The Sima de los Huesos hominid Site. J. Hum. Evol. vol. 33, 105-421.

Berger, G.W., 1994. Thermoluminescence dating of sediments older than $\sim 100 \mathrm{ka}$. Quaternary Sci. Rev. 13, 445-455.

Berger, G.W., 2011. A practical correction for sensitivity change in thermoluminescence multi-aliquot-regeneration dating of feldspar dominated fine grain loess. Radiat. Measurements 46, 1043-1054.

Berger, G.W., Pérez-González, A., Carbonell, E., Arsuaga, J.L., Bermúdez de Castro, J.M., Ku, T.L., 2008. Luminescence chronology of cave sediments at the Atapuerca paleoanthropological site, Spain. J. Hum. Evol. 55, 300-311.

Bermúdez de Castro, J.M., Arsuaga, J.L., Carbonell, E., Rosas, A., Martínez, I., Mosquera, M., 1997. A hominid from the lower Pleistocene of Atapuerca, Spain: possible ancestor to Neandertals and modern humans. Science 276, 1392-1395.

Bermúdez de Castro, J.M., Pérez-González, A., Martinón-Torres, M., GómezRobles, A., Rosell, J., Prado, L., Sarmiento, S., Carbonell, E., 2008. A new early Pleistocene hominin mandible from Atapuerca-TD6, Spain. J. Hum. Evol. 55, 729-735.

Bermúdez de Castro, J.M., Carretero, J.M., García-González, R., RodríguezGarcía, L., Martinón-Torres, M., Rosell, J., Blasco, R., Martín-Francés, L., Modesto, M., Carbonell, E., 2012. Early Pleistocene human humeri from the Gran Dolina-TD6 site (Sierra de Atapuerca, Spain). Am. J. Phys. Anthropol. 147, 604-617.

Biswas, D.K., Hyodo, M., Taniguchi, Y., Kaneko, M., Katoh, S., Sato, H., Kinugasa, Y., Mizuno, K., 1999. Magnetostratigraphy of Plio-Pleistocene sediments in a $1700-$ $m$ core from Osaka Bay, southwestern Japan and short geomagnetic events in the middle Matuyama and early Brunhes chrons. Palaeogeog. Palaeoclimatol. Palaeoecol. 148, 233-248.

Blain, H.-A., Bailon, S., Cuenca-Bescós, G., 2008. The Early-Middle Pleistocene palaeoenvironmental change based on the squamate reptile and amphibian proxy at the Gran Dolina site, Atapuerca, Spain. Palaeogeog. Palaeoclimatol. Palaeoecol. 261, 177-192.

Bosák, P., Pruner, P., 2011. Magnetic Record in Cave Sediments: a Review. In: IAGA Special Sopron Book Series.

Camps, P., et al., 2011. The Kamikatsura event and the Matuyama-Brunhes reversal recorded in lavas from Tjörnes Peninsula, northern Iceland. Earth Planetary Sci. Lett. 310, 33-44.

Canals, A., Vallverdú, J., Carbonell, E., 2003. New archaeo-stratigraphic data for the TD6 level in relation to Homo antecessor (Lower Pleistocene) at the site of Atapuerca, north-central Spain. Geoarchaeology 18 (5), 481-504.

Carbonell, E., Bermúdez de Castro, J.M., Arsuaga, J.L., et al., 1995. Lower Pleistocene hominids and artifacts from Atapuerca-TD6 (Spain). Science 269, 826-829.

Carbonell, E., García-Antón, M.D., Mallol, C., Mosquera, M., Ollé, A., Rodríguez, X.P., Sahnouni, M., Sala, R., Vergés, J.M., 1999. The TD6 level lithic industry from Gran Dolina, Atapuerca (Burgos, Spain): production and use. J. Hum. Evol. 37, 653-693.

Carbonell, E., Bermúdez de Castro, J.M., Arsuaga, J.L., Allué, E., Bastir, M., Benito, A., Cáceres, I., Canals, T., Diez, J.C., van der Made, J., Mosquera, M., Ollé, A., PérezGonzález, A., Rodríguez, J., Rodríguez, X.P., Rosas, A., Rosell, J., Sala, J., Vallverdú, J., Vergés, J.M., 2005. An early Pleistocene hominin mandible from Atapuerca-TD6, Spain. Proc. Natl. Acad. Sci. U. S. A. 102, 5674-5678.

Carbonell, E., Bermúdez de Castro, J.M., Pares, J.M., Perez-Gonzalez, A., CuencaBescos, G., Olle, A., Mosquera, M., Huguet, R., van der Made, J., Rosas, A., Sala, R., Vallverdu, J., Garcia, N., Granger, D.E., Martinon-Torres, M., Rodriguez, X.P. Stock, G.M., Verges, J.M., Allue, E., Burjachs, F., Caceres, I., Canals, A., Benito, A. Diez, C., Lozano, M., Mateos, A., Navazo, M., Rodriguez, J., Rosell, J., Arsuaga, J.L., 2008. The first hominin of Europe. Nature 452 (7186), 465-469.

Channell, J.E., Kleiven, H.F., 2000. Geomagnetic paleointensity and astronological ages for the Matuyama-Brunhes boundary and the boundaries of the Jaramillo subchron: paleomagnetic and oxygen isotope records from ODP site 983. Philosophical Transactions of the Royal Society of London A 358, 1027-1047.

Channell, J.E.T., Raymo, M.E., 2003. Paleomagnetic record at ODP site 980 (Feni drift, Rockall) for the past 1.2 Myrs. Geochem. Geophys. Geosystems G3. http:// dx.doi.org/10.1029/2002GC000440.

Channell, J.E.T., Mazaud, A., Sullivan, P., Turner, S., Raymo, M.E., 2002. Geomagnetic excursions and paleointensities in the Matuyama Chron at ocean drilling program sites 983 and 984 (Iceland Basin). J. Geophys. Res. 107 (B6), 2114. http:// dx.doi.org/10.1029/2001JB000491.
Channell, J.E.T., Curtis, J.H., Flower, B.P., 2004. The Matuyama-Brunhes boundary interval (500-900 ka) in north Atlantic drift sediments. Geophys. J. Int. 158, 489-505.

Channell, J.E.T., Hodell, D.A., Singer, B.S., Xuan, C., 2010. Reconciling astrochronological and $40 \mathrm{Ar} / 39 \mathrm{Ar}$ ages for the Matuyama-Brunhes boundary and late Matuyama Chron. Geochem. Geophys. Geosyst. 11, Q0AA12. http://dx.doi.org/ 10.1029/2010GC003203.

Coe, R.S., et al., 2004. Matuyama-Brunhes reversal and Kamikatsura event on Maui: paleomagnetic directions, ${ }^{40} \mathrm{Ar} /{ }^{39} \mathrm{Ar}$ ages and implications. Earth Planetary Sci. Lett. 222, 667-684.

Cox, S.E., Farley, K.A., Hemming, S.R., 2012. Insights into the age of the Mono Lake Excursion and magmatic crystal residence time from $(\mathrm{U}-\mathrm{Th}) / \mathrm{He}$ and ${ }^{230} \mathrm{Th}$ dating of volcanic allanite. Earth Planetary Sci. Lett. 319-320, 178-184.

Cuenca-Bescos, G., Rofes, J., Garcia-Pimienta, J.C., 2004. Paleoclima y paisaje en el Pleistoceno inferior de Atapueca: los Insectivoros (Mammalia) de los niveles inferiores de Trinchera Elefante (Burgos, Espana). Geo-Temas 6, 85-88.

Cuenca-Bescós, G., García, N., 2007. Biostratigraphic succession of the Early and Middle Pleistocene mammal faunas of the Atapuerca cave sites (Burgos, Spain) Courier Forschungsinstitut Senckenberg 259, 99-110.

Cuenca-Bescós, G., Laplana, C., Canudo, J.I., 1999. Biochronological implications of the Arvicolidae (Rodentia, Mammalia) from the Lower Pleistocene hominid-bearing level of Trinchera Dolina 6 (TD6, Atapuerca, Spain). J. Hum. Evol. 37, 353-373.

Cuenca-Bescós, G., Rofes, J., López-García, J.M., Blain, H.A., De Marfá, R.J., GalindoPellicena, M.A., Bennásar-Serra, M.L., Melero-Rubio, M., Arsuaga, J.L., Bermúdez de Castro, J.M., Carbonell, E., 2010. Biochronology of Spanish Quaternary small vertebrate faunas. Quat. Int. 212, 109-119.

Cuenca-Bescós, G., Melero-Rubio, M., Rofes, J., Martínez, I., Arsuaga, J.L., Blain, H.A López-García, J.M., Carbonell, E., Bermudez de Castro, J.M., 2011. The EarlyMiddle Pleistocene environmental and climatic change and the human expansion in Western Europe: a case study with small vertebrates (Gran Dolina, Atapuerca, Spain). J. Hum. Evol. 60, 481-491.

Cuenca-Bescós, G., Rofes, J., López-García, J.M., Blain, H.A., Rabal-Garcés, R. Sauqué, V., Arsuaga, J.L., Bermúdez de Castro, J.M., Carbonell, E., 2013. The small mammals of Sima del Elefante (Atapuerca, Spain) and the first entrance of Homo in Western Europe. Quat. Int. 295, 28-35.

Deng, et al., 2006. Magnetostratigraphic age of the XiantaiPaleolithic sitein the Nihewan Basin and implications for early human colonization of Northeast Asia. Earth Planetary Sci. Lett. 244, 336-348.

Dinares-Turell, et al., 2002. Relative geomagnetic paleointensity from the Jaramillo Subchron to the Matuyama/Brunhes boundary as recorded in a Mediterranean piston core. Earth Planetary Sci. Lett. 194, 327-341.

Doell, R.R., Dalrymple, G.B., 1966. Geomagnetic polarity epochs: a new polarity event and the age of the Brunhes-Matuyama boundary. Science 152, 1060-1061.

Duval, M., 2008. Evaluation du potentiel de la méthode de datation par Résonance de Spin Electronique (ESR) appliquée aux gisements du Pléistocène inférieur: étude des gisements d'Orce (bassin de Guadix-Baza, Espagne) et contribution à la connaissance des premiers peuplements de l'Europe (PhD thesis). Department of Prehistory, Muséum national d'Histoire naturelle, Paris, France.

Duval, M., Grün, R., Falguères, C., Bahain, J.-J., Dolo, J.-M., 2009. ESR dating of Lower Pleistocene fossil teeth: limits of the single saturating exponential (SSE) function for the equivalent dose determination. Radiat. Measurements 44, 477-482.

Duval, M., Falguères, C., Bahain, J.-J., 2012. Age of the oldest hominin settlements in Spain: contribution of the combined U-series/ESR dating method applied to fossil teeth. Quaternary Geochronology. http://dx.doi.org/10.1016/ j.quageo.2012.02.025.

Falguères, C., Bahain, J.-J., Yokoyama, Y., Arsuaga, J.L., Bermudez de Castro, J.M., Carbonell, E., Bischoff, J.L., Dolo, J.-M., 1999. Earliest humans in Europe: the age of TD6 Gran Dolina, Atapuerca, Spain. J. Hum. Evol. 37, 343-352.

Forman, S.L., 1989. Applications and limitations of thermoluminescence to date Quaternary sediments. Quat. Int. 1, 47-59.

García, N., Arsuaga, J.L., 1999. Carnivores from the Early Pleistocene hominidbearing Trinchera Dolina 6 (Sierra de Atapuerca, Spain). J. Hum. Evol. 37, $415-430$

García-Antón, M., 1995. Pollen analysis of Middle Pleistocene paleovegetation a Atapuerca. In: Bermú dez de Castro, J.M., Arsuaga, J.L., Carbonell, E. (Eds.) Human Evolution in Europe and the Atapuerca Evidence. Junta de Castilla yLeón, Valladolid, pp. 147-165.

Godfrey-Smith, D.I., Huntley, D.J., Chen, W.-H., 1988. Optical dating studies of quartz and feldspar sediment extracts. Quat. Sci. Rev. 7, 373-380.

Grün, R., Schwarcz, H.P., Chadam, J., 1988. ESR dating of tooth enamel: coupled correction for U-uptake and U-series disequilibrium. Int. J. of Rad. Appl. Inst Part D. Nucl. Tracks Radiat. Measurements 14 (1-2), 237-241.

Guyodo, Y., Richter, C., Valet, J.P., 1999. Paleointensity record from Pleistocene sediments (1.4-0 Ma) of the California Margin. J. Geophys. Res. 104, 22953-22964.

Heslop, D., Langereis, C.G., Dekkers, M.J., 2000. A new astronomical timescale for the loess deposits of Northern China. Earth Planetary Sci. Lett. 184, 125-139.

Huntley, D.J., Lamothe, M., 2001. Ubiquity of anomalous fading in K-feldspars and the measurement and correction for it in optical dating. Can. J. Earth Sci. 38 $1093-1106$

Izett, G.A., Obradovich, J.D., $1994 .{ }^{40} \mathrm{Ar} /{ }^{39} \mathrm{Ar}$ age constraints for the Jaramillo Normal Subchron and the Matuyama-Brunhes geomagnetic boundary. J. Geophys. Res. 99, 2925-2934.

Joannes-Boyau, R., Grün, R., 2011. A comprehensive model for CO2-radicals in fossil tooth enamel: implications for ESR dating. Quat. Geochronology 6 (1), 82-97. 
Kirschvink, J.L., 1980. The least-squares line and plane and the analysis of paleomagnetic data. Geophys. J. R. Astronom. Soc. 62, 699-718.

Kok, Y.S., Tauxe, L., 1999. A relative paleointensity stack from Ontong-Java Plateau sediments for the Matuyama. J. Geophys. Res. 104, 25401-25413.

Laj, C., Channell, J.E.T., 2007. Geomagnetic excursions. In: Kono, M. (Ed.), Treatise in Geophysics, vol. 5. Elsevier, pp. 373-416.

Latham, A.G., Ford, D.C., 1993. The paleomagnetism and rock magnetism of cave and karst deposits. In: Applications of Paleomagnetism to Sedimentary Geology, 49. SEPM Spec. Publ, pp. 149-155.

Lisiecki, L.E., Raymo, M.E., 2005. A Pliocene-Pleistocene stack of 57 globally distributed benthic 180 records. Paleoceanography 20, PA1003. http:// dx.doi.org/10.1029/2004PA001071.

Liu, P., Deng, C., Li, S., Zhu, R., 2010. Magnetostratigraphic dating of the Huojiadi Paleolithic site in the Nihewan Basin, North China. Palaeogeography, Palaeoclimatology, Palaeoecology 298, 399-408. http://dx.doi.org/10.1016/ j.palaeo.2010.10.027.

Lourens, L., Hilgen, F., Shackleton, N.J., Laskar, J., Wilson, D., 2004. The Neogene period, chapter 21. In: F. Gradstein, Ogg, J., Smith, A.G. (Eds.), A Geologic Time Scale. Cambridge University Press, pp. 409-440.

Lund, S.P., Acton, G.D., Clement, B., Okada, M., Williams, T., 2001. Brunhes chron magnetic field excursions recovered from Leg 172 sediments. In: Keigwin, L.D., 27. Rio, D., Acton, G.D., Arnold, E. (Eds.), Proc. ODP Sci. Results, 172, pp. 1-18.

Made, J. van der, 1999. Ungulates from Atapuerca TD6. J. Hum. Evol. 37, 389-413.

Maenaka, K., 1983. Magnetostratigraphic Study of the Osaka Group, with Specia Reference to the Existence of Pre and Past-Jaramillo Episodes in the Late Matuyama Polarity Epoch 14. Mem. Hanazono Univ, pp. 1-65.

Mankinen, E.A., Donnelly-Nolan, J.M., Gromme, C.S., Hearn, B.C., 1981. Paleomagnetism of the Clear Lake Volcanics and New Limits on the Age of the Jaramillo Normal Polarity Event, vol. 1141. United States Geological Survey, pp. 67-82. Professional Paper.

Martín, M.A., Domingo, S., Antón, T., 1981. Estudio de las cavidades de la zona BUIV-A (Sierra de Atapuerca). In: KAITE Estudios de espelología burgalesa. Grupo Espeleológico Edelweiss, Burgos, Spain, pp. 41-75.

Moreno, D., 2011. Datation par ESR de quartz optiquement blanchis (ESR-OB) de région de Atapuerca (Burgos, Espagne). In: Application au site préhistorique de Gran Dolina (contexte karstique) et aux systèmes fluviatiles quaternaires de l'Arlanzón et l'Arlanza. Departament d'Història i Història de l'Art. Universitat Rovira i Virgili, Tarragona, Spain (Ph.D. thesis).

Moreno, D., Falguères, C., Pérez-González, A., Duval, M., Voinchet, P., BenitoCalvo, A., Ortega, A.I., Bahain, J.-J., Sala, R., Carbonell, E., 2011. ESR chronology of alluvial deposits in the Arlanzon Valley (Atapuerca, Spain): correlation with Gran Dolina archaeological site. In: 13th International Conference on Luminescence and Electron Spin Resonance Dating, 10-14 July 2011, Torun, Poland, p. 141. Book of Abstracts.

Oms, O., Parés, J.M., Martínez-Navarro, B., Agustí, J., Toro, I., Martínez-Fernández, G., Turq, A., 2000. Early human occupation of Western Europe: paleomagnetic dates for two paleolithic sites in Spain. Proc. Natl. Acad. Sci. U. S. A. 97, 10666-10670.

Ortega, A.I., Benito-Calvo, A., Porres, J., Pérez-González, Martín-Merino, A. 2010. Applying Electrical ResistivityTomography to the Identification of Endokarstic Geometries inthe Pleistocene Sites of the Sierra de Atapuerca (Burgos, Spain) Archaeol. Prospect 17, 233-245.

Parés, J.M., Pérez-González, A., 1995. Paleomagnetic age for hominid fossils at Atapuerca Archaeological site, Spain. Science 269, 830-832.

Parés, J.M., Perez-González, A., 1999. Magnetochronology and stratigraphy at Gran Dolina section, Atapuerca (Burgos, Spain). J. Hum. Evol. 37, 325-342.

Parés, J.M., Pérez-Gonzalez, A., Rosas, A., Benito, A., Bermúdez de Castro, J.M. Carbonell, E., Huget, R., 2006. Matuyama-Age Lithic Tools in the "Sima del Elefante" Site, Atapuerca (N Spain). J. Hum. Evol. 50, 163-169.
Perkins, A., Maher, B., 1993. Rock magnetic and palaeomagnetic studies of British speleothems. Journal of Geomagnetism and Geoelectricity 45, 143-153.

Pérez-González, A., Aleixandre, T., Pinilla, A., Gallardo, J., Benayas, J., Martínez, M.J., Ortega, A.I., 1995. An approach to the Galeria stratigraphy in the Sierra de Atapuerca trench (Burgos). In: Bermúdez de Castro, J.M., Arsuaga, J.L., Carbonell, E. (Eds.), Human Evolution in Europe and the Atapuerca Evidence. Junta de Castilla y León, Consejería de Cultura y Turismo, Valladolid, Spain, pp. 99-122.

Pérez-González, A Parés, JM., Carbonell, E Aleixandre, T, Ortega, A.I., Benito, A. Merino, M.A.M., 2001. Géologie de la Sierra de Atapuerca et stratigraphie des remplissages karstiques de Galería et Dolina (Burgos, Espagne). L'Anthropologie 105, 27-43.

Pineda, A. 1997. Mapa Geológico de España escala 1:50.000, 2a Serie (MAGNA). Hoja de Burgos, 200 (19-10). IGME. Serv. Pub. M Industria, Madrid.

Roberts, R.G., 1997. Luminescence dating in archaeology: from origins to optical. Radiat. Measurements 27, 819-892.

Rodriguez, J., Burjachs, F., Cuenca-Bescós, G., García, N., Van der Made, J., Pérez, A., Blain, H.-A., Expósito, I., López García, J.M., García Antón, M., Allué, E., Cáceres, I., Huguet, R., Mosquera, M., Ollé, A., Rosell, J., Parés, J.M., Rodriguez, X.P., Diez, C., Rofes, J., Sala, R., Saladié, P., Vallverdú, J., Bennasar, M.L., Blasco, R., Bermúdez de Castro, J.M., Carbonell, E., 2011. One million years of cultural evolution in a stable environment at Atapuerca (Burgos, Spain). Quaternary Science Reviews $30,1396-1412$

Sánchez-Marco, A., 1999. Implications of the avian fauna for paleoecology in the Early Pleistocene of Iberian Peninsula. J. Hum. Evol. 37, 375-388.

Shackleton, N.J., Berger, A., Peltier, W.R., 1990. An alternative astronomical calibration of the lower Pleistocene timescale based on ODP Site 677. Trans. R. Soc. Edinburgh: Earth Sci. 81, 251-261.

Singer, B.S., Brown, L.L., 2002. The Santa Rosa event: 40Ar/39Ar and paleomagnetic results from the Valle Grande Rhyolite near Jaramillo Creek, Jemez mountains, new Mexico. Earth Planetary Sci. Lett. 197, 51-64.

Singer, B., Hoffman, K.A., Chauvin, A., Coe, R.S., Pringle, M.S., 1999. Dating transitionally magnetized lavas of the late Matuyama Chron: toward a new 40Ar 39Ar timescale of reversals and events. J. Geophys. Res. 104, 679-693.

Spell, T.L., McDougall, I., 1992. Revisions to the age of the Matuyama-Brunhes boundary and the Pleistocene polarity timescale. Geophys. Res. Lett. 19, 11811184.

Stokes, S., 1999. Luminescence dating applications in Geomorphological research. Geomorphology 29, 153-171.

Torres, T.J., 1976. El karst de la Sierra de Atapuerca. Cuadernos de Arqueología de Deusto 1, 13-15.

Valet, J.P., Meynadier, L., 1993. Geomagnetic field intensity and reversals during the past four million years. Nature 366, 234-238.

Valet, J., Meynadier, L., Guyodo, Y., 2005. Geomagnetic dipole strength and reversal rate over the past two million years. Nature 435, 802-805.

Valet, et al., 2008. Geomagnetic excursions reflect an aborted polarity state. Earth Planetary Sci. Lett. 274, 472-478.

Wintle, A.G., 1973. Anomalous fading of thermoluminescence in mineral samples. Nature 245, 143-144.

Yang, T., Hyodo, M., Yang, Z., Fu, J., 2004. Evidence for the Kamikatsura and Santa Rosa excursions recorded in eolian deposits from the southern Chinese Loess plateau. J. Geophys. Res. 109, B12105. http://dx.doi.org/10.1029/ 2004JB002966.

Zazo, C., Goy, J.L., Hoyos, M., 1983. Estudio geomorfológico de los alrededores de la Sierra de Atapuerca (Burgos). Estudios Geol. 39, 179-185.

Zijderveld, J.D.A., 1967. AC demagnetization of rocks: analysis of results. In: Collinson, D.W., Runcorn, S.K., Creer, K.M. (Eds.), Methods in Paleomagnetism. Elsevier, New York, pp. 254-286. 